\section{Microbiological analysis of the Robiola di Roccaverano cheese by means of traditional culturing methods} Federica Biolcati, Maria Teresa Bottero,
Alessandra Dalmasso

Department of Veterinary Science, University of Turin, Italy

\begin{abstract}
Robiola di Roccaverano is a Protected Designation of Origin soft cheese made with goat's milk, produced in Piedmont region (Italy). The peculiarities of this cheese are: i) the use of the raw milk, ii) the addition of a Natural Milk Starter, iii) the application of traditional techniques of production and iv) the localization of the dairies in rural area. All these aspects influence the microbial flora of final product and make interesting its investigation. Samples were collected at different moment of the cheese making process and during the different seasons. In this preliminary study, the safety and the hygiene parameters of the production were evaluated. Lactic acid bacteria, moulds and yeasts involved in cheese-making process were also enumerated. Pathogens were not found in all samples and the counts of coagulase positive staphylococci were within the standard of law. The enumeration of microorganisms of technological interest demonstrated that, nevertheless the artisanal manufacturing process applied, the dairy was able to standardize the final products.
\end{abstract}

\section{Introduction}

Italy possesses an ancient tradition in the manufacturing of dairy products, with a wide variety of typical cheese that has received the Protected Designation of Origin (PDO) status. Among these, the Robiola di Roccaverano is an artisanal, soft and creamy cheese, made with raw goat's milk in the Piedmont region (North-West Italy). During the production process a Natural Milk Starter (NMS) obtained from the milk acidification coming from previous fermentation process, is inoculated into fresh raw milk. Thereafter, curd obtained from goat's or cow's rennet is overturned into mold for the serum release and after 4 days Robiola di Roccaverano cheese can be sold as fresh cheese or ripened for maximum 15 days. Consequently, safety and quality of Robiola di Roccaverano cheese are strictly related to the indigenous microflora inhabiting unpasteurized milk, NMS and to the hygienic conditions of dairy environment.

Due to the importance of the microflora on the characteristics of the final product, in recent years, several researches focused on the investigation of the microbial composition and population dynamics of artisanal dairy products. In particular, numerous researches have been conducted on traditional raw milk cheese (Yunita and Dodd, 2018; Picon et al., 2016; Quigley et al., 2011). Robiola di Roccaverano has been already investigated through classical microbiology in studies have been focused on cheese coming from different dairies and periods of the year (Bonetta et al., 2008).

This is the first study in which the evolution of microbial flora in the different steps of production and the importance of the NMS during the manufacturing process have been assessed. The aims of this preliminary work were to monitor food safety and hygienic parameters, as well as microorganisms of technological interest like Lactic Acid Bacteria (LAB), moulds and yeasts. The samples were collected along the production chain and in different period of the year.

\section{Materials and Methods}

\section{Microbiological analysis and pH detection}

NMS $(\mathrm{N}=12)$, raw milk $(\mathrm{N}=12), 5$ days ripened cheese $(\mathrm{N}=12)$ and 15 days ripened cheese $(\mathrm{N}=12)$ were sampled, in different seasons of the year (spring, summer, autumn and winter). Three samples of each matrix were collected in different production days, in sterile conditions from one of the most appreciated Robiola di Roccaverano cheese factory and analyzed within 2-3 h of sampling. Ten grams or 10 $\mathrm{ml}$ of each sample were firstly homogenized with a sterile physiological saline solution and peptone (85:15 v:v, $90 \mathrm{~mL}$ ) (Oxoid Limited, Basingstoke, UK) using the Stomacher 400 Circulator (Seward Limited, Worthing, UK) at $230 \mathrm{rpm}$ for 1 min. Subsequently, serial dilutions were prepared with the same saline solution. The number of Coagulase Positive Staphylococci (CPS) were evaluated at $37^{\circ} \mathrm{C}$ for $24-48 \mathrm{~h}$ on Baird-Parker RPF Agar (Oxoid Limited, Basingstoke, UK). Instead the enumeration of Enterobacteriaceae was performed on VRBGA (Oxoid Limited, Basingstoke, UK).

The food safety parameters released by the European Commission (EC) Regulation $2073 / 2005$ were evaluated in milk and
Correspondence: Federica Biolcati, Department of Veterinary Science, University of Turin, Largo Braccini 2, 10095 Grugliasco (TO), Italy.

Tel.: +39.011.6709219.

E-mail: federica.biolcati@unito.it

Key words: Robiola di Roccaverano, Lactic acid bacteria, Mould, Yeast, Safety.

Contributions: the authors contributed equally.

Conflict of interest: the authors declare no potential conflict of interest.

Funding: this work was supported by a grant of University of Turin [ex 60\%]

Received for publication: 24 Septmber 2019. Revision received: 4 October 2019.

Accepted for publication: 31 October 2019.

This work is licensed under a Creative Commons Attribution-NonCommercial 4.0 International License (CC BY-NC 4.0).

(C) Copyright: the Author(s), 2019

Licensee PAGEPress, Italy

Italian Journal of Food Safety 2019; 8:8574

doi:10.4081/ijfs.2019.8574

cheese samples. In particular, the presence of Salmonella spp. and Listeria monocytogenes were monitored according to standard methods (European Commission Regulation No 2073/2005). Furthermore, microorganisms of technological interest like LAB (lactobacilli and lactococci), moulds and yeasts were analyzed. Lactobacilli and lactococci were grown on MRS agar (Oxoid Limited, Basingstoke, $\mathrm{UK})$ at $31^{\circ} \mathrm{C}$ in anaerobic conditions for 24$48 \mathrm{~h}$, and M17 agar in aerobic conditions overnight (Oxoid Limited, Basingstoke, UK) at $31{ }^{\circ} \mathrm{C}$ respectively. Moulds and yeasts were grown on OGYE agar (Oxoid Limited, Basingstoke, UK) at $25^{\circ} \mathrm{C}$ for 5 days. All the parameters above mentioned were analyzed in raw milk, 5 days cheese and 15 days cheese samples; instead NMS were investigated only for microorganism of technological interest such as LAB, moulds and yeasts. Finally, the $\mathrm{pH}$ measurements of milk, NMS, 5 days cheese and 15 days cheese were performed as reported by ISO 2917:1999 within 2-3 hours after sampling.

\section{Statistical analysis}

All samples were tested in triplicate and the bacterial counts were expressed as Log $\mathrm{CFU} / \mathrm{g}$ or Log CFU/mL. One-way analysis of variance (ANOVA) was used to determine statistically significant differences $(\mathrm{P}<0.05)$ among the independent variables 
Table 1. Results of classical microbiological analysis.

\begin{tabular}{|c|c|c|c|c|c|c|c|}
\hline Matrices & Season & ENT & CPS & Lactococci & Lactobacilli & M\&Y & $\mathrm{pH}$ \\
\hline Milk & Spring & 2,7 & 3,8 & 3,8 & 3,7 & 2,5 & 6,7 \\
\hline Milk & Spring & 2,0 & 3,1 & 3,9 & 3,3 & 3,4 & 6,8 \\
\hline Milk & Spring & 2,7 & 3,5 & 6,5 & 2,8 & 3,8 & 6,6 \\
\hline Milk & Summer & 4,1 & 3,7 & 6,5 & 4,8 & 5,5 & 6,7 \\
\hline Milk & Summer & 3,0 & 2,3 & 2,5 & 2,0 & 2,5 & 6,3 \\
\hline Milk & Summer & 3,5 & 4,1 & 5,7 & 5,9 & 4,2 & 6,5 \\
\hline Milk & Autumn & 3,2 & 3,0 & 3,4 & 3,5 & $<2,0$ & 6,5 \\
\hline Milk & Autumn & 3,1 & 3,7 & 3,6 & 3,6 & $<2,0$ & 6,5 \\
\hline Milk & Autumn & 3,1 & 3,5 & 3,8 & 3,5 & $<2,0$ & 6,5 \\
\hline Milk & Winter & 2,0 & 3,4 & 4,2 & 3,4 & $<2,0$ & 6,7 \\
\hline Milk & Winter & 3,5 & 3,8 & 3,7 & 3,3 & $<2,0$ & 6,5 \\
\hline Milk & Winter & 3,6 & 3,1 & 3,2 & 3,0 & $<2,0$ & 6,4 \\
\hline NMS & Spring & - & - & 9,4 & 8,9 & 3,5 & 4,8 \\
\hline NMS & Spring & - & - & 9,4 & 9,1 & 6,5 & 4,8 \\
\hline NMS & Spring & - & - & 8,7 & 8,3 & 9,5 & 4,7 \\
\hline NMS & Summer & - & - & 7,9 & 7,1 & 7,9 & 4,8 \\
\hline NMS & Summer & - & - & 8,9 & 8,5 & 3,6 & 4,3 \\
\hline NMS & Summer & - & - & 8,1 & 6,4 & 4,0 & 4,8 \\
\hline NMS & Autumn & - & - & 9,1 & 8,1 & 2,9 & 5,0 \\
\hline NMS & Autumn & - & - & 9,0 & 8,9 & 3,8 & 4,9 \\
\hline NMS & Autumn & - & - & 9,1 & 9,7 & 2,5 & 4,3 \\
\hline NMS & Winter & - & - & 8,3 & 8,3 & 2,4 & 4,7 \\
\hline NMS & Winter & - & - & 9,2 & 8,6 & 2,4 & 4,7 \\
\hline NMS & Winter & - & - & 9,0 & 7,5 & 2,6 & 4,7 \\
\hline 5 days cheese & Spring & 1,2 & 3,1 & 8,2 & 7,1 & 4,2 & 4,8 \\
\hline 5 days cheese & Spring & 2,5 & $<2,0$ & 6,5 & 5,8 & 5,8 & 4,5 \\
\hline 5 days cheese & Spring & 4,9 & $<2,0$ & 7,9 & 6,8 & 6,7 & 4,6 \\
\hline 5 days cheese & Summer & $<1,0$ & 2,3 & 7,5 & 8,3 & 7,1 & 4,2 \\
\hline 5 days cheese & Summer & $<1,0$ & 2,8 & 7,7 & 7,3 & 7,2 & 4,5 \\
\hline 5 days cheese & Summer & 2,2 & 2,9 & 8,1 & 7,4 & 7,6 & 4,8 \\
\hline 5 days cheese & Autumn & 2,9 & 3,0 & 8,7 & 8,1 & 8,4 & 4,6 \\
\hline 5 days cheese & Autumn & 2,7 & 2,4 & 7,8 & 8,2 & 8,2 & 4,7 \\
\hline 5 days cheese & Autumn & 2,5 & 2,5 & 8,1 & 8,5 & 7,6 & 4,8 \\
\hline 5 days cheese & Winter & 2,6 & 2,0 & 8,2 & 7,4 & 7,8 & 4,9 \\
\hline 5 days cheese & Winter & 2,5 & 2,3 & 8,4 & 3,8 & 7,6 & 4,6 \\
\hline 5 days cheese & Winter & 4,3 & $<2,0$ & 8,2 & 7,9 & 7,8 & 4,9 \\
\hline 15 days cheese & Spring & 4,1 & 3,1 & 8,3 & 8,0 & 8,5 & 4,7 \\
\hline 15 days cheese & Spring & 3,5 & 2,5 & 7,9 & 7,6 & 8,2 & 5,0 \\
\hline 15 days cheese & Spring & 3,5 & 2,6 & 8,7 & 8,3 & 8,0 & 4,9 \\
\hline 15 days cheese & Summer & 1,2 & 2,0 & 9,2 & 8,7 & 7,4 & 4,7 \\
\hline 15 days cheese & Summer & 4,2 & 3,1 & 8,3 & 8,0 & 8,8 & 4,8 \\
\hline 15 days cheese & Summer & 2,5 & 3,6 & 8,4 & 7,9 & 7,8 & 4,7 \\
\hline 15 days cheese & Autumn & 2,5 & 3,1 & 8,3 & 8,4 & 7,8 & 4,9 \\
\hline 15 days cheese & Autumn & 2,4 & 3,2 & 8,4 & 8,1 & 8,0 & 4,8 \\
\hline 15 days cheese & Autumn & 3,1 & 2,6 & 8,3 & 8,4 & 8,0 & 4,9 \\
\hline 15 days cheese & Winter & 2,5 & 2,5 & 8,3 & 8,0 & 7,9 & 4,8 \\
\hline 15 days cheese & Winter & $<1,0$ & $<2,0$ & 8,3 & 8,1 & 7,6 & 4,8 \\
\hline 15 days cheese & Winter & 2,4 & $<2,0$ & 8,4 & 8,0 & 7,6 & 4,9 \\
\hline
\end{tabular}

All results were expressed as Log CFU/mL or Log CFU/g. Abbreviations: Enterobacteriaceae (ENT), coagulase positive staphylococci (CPS), Moulds and Yeasts (M\&Y) and Natural Milk Starter (NMS). $<1$ and $<2$ are the limits of detection of the methods. 
such as microbiological parameters and seasonality. Where significances were assessed, post hoc test was conducted using Tukey multiple comparison test.

Principal Component Analysis (PCA) using PAST software version 3 (Hammer, Harper, \& Rian, n.d.) was performed in order to characterize microbial communities in different samples of milk, 5- and 15days collected in one year.

\section{Results and Discussion}

The results obtained by culturing methods are summarized in Table 1.

The safety parameters complained with food safety criteria of EC Regulation 2073/2005, since pathogenic microorganisms such as L. monocytogenes and Salmonella spp. were not found in all milk and cheese samples. These results supported those obtained by several studies aimed to characterize cheese obtained with unpasteurized milk such as malga cheese and Kashkaval (Lucchini et al., 2018; Pappa et al., 2019; Yoon et al., 2016).

The values of CPS in milk ranged between 2.3 and 4.1 Log CFU/mL, instead in cheeses CPS were not detected in some samples and, in general, they were lower than 3.6 Log CFU/g. Despite the small variation among the samples, the total counts of CPS were always within the required limits of processing hygiene criteria included in
EC Regulation 2073/2005. The results obtained can be considered promising in relation to the absence of thermal treatment of raw materials, to the location of dairy in rural areas and to the artisanal manufacturing process employed.

Beside food safety aspect, the quantification of Enterobacteriaceae colonies could be used as parameter of hygiene and quality of productions. In fact, high counts of colonies belonging to this family in milk and cheese could be an indicator of poor hygienic conditions of production (Tornadijo et al., 2001). The count of Enterobacteriaceae in milk (2.0-4.1 Log $\mathrm{CFU} / \mathrm{mL}$ ) were similar than those reported in cow's milk and lower than the goat's milk used for the production of Tenerife cheese (Tornadijo et al., 2001, Zárate et al., 1997). In addition, Enterobacteriaceae values were similar among milk, 5 days cheese and 15 days cheese samples. In the past some authors described that the number of Enterobacteriaceae decreased with the maturation time (Metz et al., 2020). However, our findings contrasted with the trend above described probably due to the short time of ripening of Robiola di Roccaverano.

Concerning the microorganisms of technological interest like $\mathrm{LAB}$, the counts in milk were between 2.5-6.5 log CFU/mL for the lactococci and within 2.0-5.9 $\mathrm{log}$ $\mathrm{CFU} / \mathrm{mL}$ for lactobacilli, less than the values reported by Quigley et al. (2013). No significant differences were observed among milk samples and seasons.
For as concern moulds and yeast counts, milk samples can be divided in two main groups due the significant seasonal difference $(\mathrm{P}<0.005)$. In fact, spring and summer showed similar quantity within 2.5 and $5.5 \mathrm{Log} \mathrm{CFU} / \mathrm{mL}$, instead in autumn and winter mould and yeasts were not detectable with culturing methods. The lack of fungal colonies isolated in cold seasons may depend on the inability of culturing methods to detect population present in low amount (Dalmasso et al., 2016). In addition, the seasonality differences observed could be related to the variable environmental dairy conditions or to the un-standardized manufacturing procedures.

Furthermore, NMS lactic flora showed high quantity of lactococci and lactobacilli, between 7.9 and 9.4 Log CFU/mL and 6.4 and 9.7 Log CFU/mL respectively, similar among the different seasons; as well as mould and yeast were present always in similar number within 2.4 and $9.5 \mathrm{Log}$ CFU/mL (Table 1).

Samples of 5 days cheese and 15 days cheese contained high number of lactococci and lactobacilli, as the values found in NMS (between 3.8 and $9.2 \log \mathrm{CFU} / \mathrm{g}$ ). High quantity of LAB was reported in Robiola di Roccaverano and in other raw milk cheese (Bonetta et al., 2008; Poznanski et al., 2004). No differences were found in LAB number among seasons. Indeed, mould and yeast counts in the two types of cheese were within 4.2 and $8.8 \mathrm{Log}$ CFU/g. Significant seasonal differences were found also in 5

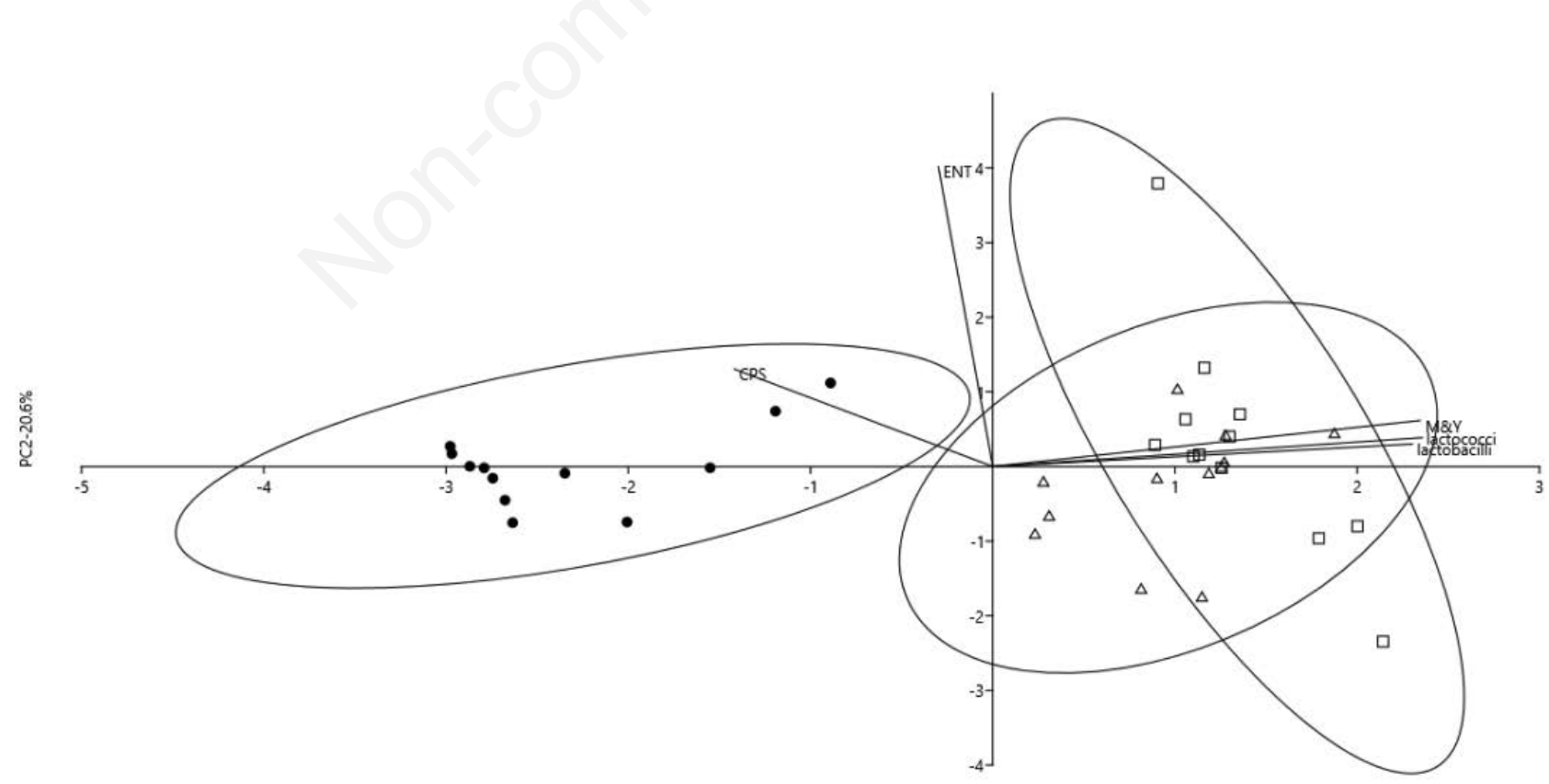

PC1-60.9\%

Figure 1. Principal Component Analysis plot of all microbiological parameters for milk, 5- and 15- days cheese. Abbreviations: Enterobacteriaceae (ENT), coagulase positive staphylococci (CPS), Moulds and Yeasts (M\&Y). 
days cheeses collected in spring season vs winter and autumn $(\mathrm{P}<0.005)$.

On the contrary to milk samples, where in autumn and winter moulds and yeasts were not isolated, in 5 days cheese they were found in high number. This increment could depend by the addition of NMS or by dairy environmental sources.

Generally, the microflora dynamic described in our results was characterized by the increasing of LAB, moulds and yeasts population from milk to cheese $(\mathrm{P}<0.005)$ after the addition of NMS. Probably, the high number of technological populations in NMS strongly influenced the final products. This tendency has been largely observed during cheese manufacturing process and in others goat's milk cheese (Psoni and Tzanetakis, 2003; Zárate et al., 1997).

The $\mathrm{pH}$ of milk samples showed values between 6.3 and 6.8, instead NMS, 5 days cheese and 15 days cheese reached $\mathrm{pH}$ value comprise among 4.2 and 5.0. The low $\mathrm{pH}$ in NMS could be ascribed to the action of LAB that rapidly ferment lactose to lactic acid, especially, mesophilic lactococci (Wouters et al., 2002). Therefore, the addition of NMS to fresh raw milk during Robiola di Roccaverano manufacturing rapidly reduced $\mathrm{pH}$ value; as well as low $\mathrm{pH}$ persisted in 5 days and 15 days cheeses. During the cheese-making process the acidification is an important parameter for milk coagulation. Moreover the combined effect of low $\mathrm{pH}$ and high number of LAB may prevent the growth of undesirable microorganisms like $S$. aureus and L. monocytogenes (Lucchini et al., 2018; Schelin et al., 2011; Yoon et al., 2016).

Finally, in order to investigate the clustering tendency between milk, 5 days cheese and 15 days cheese the PCA was performed (Figure 1). This test allowed to better describe the results reported in Table 1. The samples clustered separately according to the type of matrices: milk disclosed along the second principal component from cheese, instead no separation was found among fresh and matured cheese. In reason of these results above mentioned, 5- and 15days cheese were separated to milk for the component $\mathrm{LAB}$ mould and yeast.

\section{Conclusions}

In this preliminary work the production chain of an artisanal cheese factory of Robiola di Roccaverano was followed for one year. Despite the absence of thermal treatment of raw material, the small-scale of the dairy and the artisanal manufacturing methodologies adopted, no pathogens were found in milk and cheese products. Even though the traditional cheese making process, the dairy was able to guarantee good quality standards in the Robiola di Roccaverano, confirmed by reduced differences in terms of microbial enumeration along one year. Further research will be necessary to investigate the microbiota and organoleptic features of this artisanal production, other than compare different dairies of Robiola di Roccaverano cheese.

\section{References}

Bonetta S, Coïsson JD, Barile D, Bonetta S, Travaglia F, Piana G, Carraro E, Arlorio M, 2008. Microbiological and chemical characterization of a typical Italian cheese: Robiola di Roccaverano. J Agric Food Chem 56:7223-30.

Dalmasso A, Soto del Rio M de los D, Civera T, Pattono D, Cardazzo B, Bottero MT, 2016. Characterization of microbiota in Plaisentif cheese by highthroughput sequencing. LWT - Food Sci Technol 69:490-6.

European Commission, 2005. Commission Regulation (EC) of 15 November 2005 on microbial criteria for foodstuffs. 2073/2005/CE. In: Official Journal. L338/1. 22/12/2005.

Lucchini R, Cardazzo B, Carraro L, Negrinotti M, Balzan S, Novelli E, Fasolato L, Fasoli F, Farina G, 2018. Contribution of natural milk culture to microbiota, safety and hygiene of raw milk cheese produced in alpine malga. Ital J Food Saf 7:55-61.

Metz M, Sheehan J, Feng PCH, 2020. Use of indicator bacteria for monitoring sanitary quality of raw milk cheeses - A literature review. J Food Microbiol 85:103283.

Pappa EC, Kondyli E, Samelis J, 2019. Microbiological and biochemical char- acteristics of Kashkaval cheese produced using pasteurised or raw milk. Int Dairy J 89:60-7.

Picon A, Garde S, Ávila M, Nuñez M, 2016. Microbiota dynamics and lactic acid bacteria biodiversity in raw goat milk cheeses. Int Dairy J 58:14-22.

Poznanski E, Cavazza A, Cappa F, Cocconcelli PS, 2004. Indigenous raw milk microbiota influences the bacterial development in traditional cheese from an alpine natural park. Int J Food Microbiol 92:141-51.

Psoni L, Tzanetakis N, 2003. Microbiological characteristics of Batzos, a traditional Greek cheese from raw goat's milk. Food Microbiol 20:575-82.

Quigley L, O'Sullivan O, Beresford TP, Ross RP, Fitzgerald GF, Cotter PD, 2011. Molecular approaches to analysing the microbial composition of raw milk and raw milk cheese. Int $\mathrm{J}$ Food Microbiol 150:81-94.

Quigley L, O'Sullivan O, Stanton C, Beresford TP, Ross RP, Fitzgerald GF, Cotter PD, 2013. The complex microbiota of raw milk. FEMS Microbiol Rev 37:664-98.

Schelin J, Wallin-carlquist N, Cohn MT, Barker GC, Schelin J, Wallin-carlquist N, Cohn MT, Lindqvist R, 2011. The formation of Staphylococcus aureus enterotoxin in food environments and advances in risk assessment. Virulence 2:580-92.

Tornadijo ME, Garc MC, Fresno JM, Carballo J, 2001. Study of Enterobacteriaceae during the manufacture and ripening of San Simón cheese. Food Microbiol 18:499-509.

Wouters JTM, Ayad EHE, Hugenholtz J, Smit G, 2002. Microbes from raw milk for fermented dairy products. Int Dairy J 12:91-109.

Yoon Y, Lee S, Choi KH, 2016. Microbial benefits and risks of raw milk cheese. Food Control 63: 201-15.

Yunita D, Dodd CER, 2018. Microbial community dynamics of a blue-veined raw milk cheese from the United Kingdom. J Dairy Sci 101:4923-35.

Zárate V, Belda, F, Pérez C, Cardell E, 1997. Changes in the Microbial Flora of Tenerife Goats' Milk Cheese During Ripening. Int Dairy J 6946:635-41. 